\title{
Um clássico provinciano: Minha vida de menina, de Helena Morley
}

\author{
A provincial classic: The Diary of "Helena Morley" \\ Patrícia Cristine HOFF* \\ Universidade Federal do Rio Grande do Sul (UFRGS)
}

\begin{abstract}
RESUMO: Minha vida de menina, de Helena Morley (pseudônimo de Alice Dayrell Caldeira Brant) e publicado em 1942, estrutura-se na forma de um diário e relata diversos episódios vividos pela adolescente Helena entre os anos de 1893 e 1895 na cidade mineira de Diamantina. No seu estudo desse texto, o presente artigo divide-se em duas partes. A primeira parte dará conta de alguns aspectos da obra, considerando a adoção da escrita autobiográfica em gênero diário e tendo em perspectiva as categorias autor, narrador e personagem. A segunda parte trará algumas das diferentes temáticas suscitadas por essa obra, contando com o auxílio de uma parcela da fortuna crítica disponível.
\end{abstract}

PALAVRAS-CHAVE: Minha vida de menina. Escrita autobiográfica. Aspectos temáticos.

ABSTRACT: The Diary of "Helena Morley", written by Helena Morley (pseudonym of Alice Dayrell Caldeira Brant) and published in 1942, is structured in the form of a diary and recounts several episodes experienced by teen Helena between 1893 and 1895 in the city of Diamantina, Minas Gerais, Brazil. In the study of the book, this article is divided into two parts. The first part discusses a range of aspects of the text taking into account the adoption of the autobiographical writing in the diary as a literary genre, considering the literary categories of author, narrator, and character. The second part presents some of the themes raised by the critical reception of this book.

KEYWORDS: The Diary of "Helena Morley". Autobiography writing. Themes.

Recebido em 18 de outubro de 2016. Aprovado em 28 de novembro de 2016.

\footnotetext{
* Doutoranda em Teoria, Crítica e Comparatismo do Programa de Pós-Graduação em Letras da Universidade Federal do Rio Grande do Sul (UFRGS). Porto Alegre, Brasil, e-mail: patriciacristine.hoff@gmail.com.
} 


\section{Primeira parte: o pacto instável}

Um dos aspectos que faz um diário tradicional ser admirado pelos seus leitores, dos comuns aos especializados, é a sua voz autoral, a qual revela um gênio, uma forte personalidade, que é também histórica. O resultado disso é o pacto: o leitor espera que o que está sendo relatado na linearidade dos dias não seja irremediavelmente penetrado pela ficção e que se permaneça garantido pela verificação dos fatos apresentados em provas do mundo ao qual a narrativa faz referência - diferentemente do que costuma acontecer em relação aos diários ficcionais e demais gêneros literários não autobiográficos, nos quais, a rigor, as relações, estabelecidas pelo leitor, entre plano narrativo e contexto histórico (psicológico, social, político, cultural etc.) são menos imediatas. Acontece que nos diários íntimos e em outros gêneros da escrita de si fica com frequência estabelecida a identidade entre as categorias autor, narrador e personagem (o que origina o pacto autobiográfico, nos termos de Philippe Lejeune ${ }^{1}$ ), identidade que, ao centrar-se no sujeito, avizinha-se mais facilmente do leitor.

Tais categorias ${ }^{2}$, contudo, não são de todo definidas e fixas, constituindo-se em repetidos problemas e suscitando reflexões por parte da recepção e da crítica. O pacto pode ser, então, instável, constantemente desestabilizado em função da abertura e da singularidade das obras literárias. Assim, ainda que observemos a criação desse pacto em Minha vida de menina, de Helena Morley, publicado em 1942, a ficcionalização de alguns aspectos formais não pode ser veementemente negada. A começar pela categoria autor.

"Helena Morley" é o pseudônimo que Alice Dayrell Caldeira Brant (1880$1970)^{3}$ adota para instituir a autoria dos diários da adolescente Helena, que relata

${ }^{1}$ LEJEUNE, Philippe. O pacto autobiográfico: de Rousseau à Internet. Trad. Jovita Maria Gerheim Noronha e Maria Inês Coimbra Guedes. Belo Horizonte: Ed. UFMG, 2008. (Coleção Humanitas).

$2 \mathrm{Na}$ esteira dos estudos sobre narrativas autobiográficas, essa separação entre autor, narrador e personagem serve aqui mais como um procedimento didático do que como uma construção teórica de um forte rigor metodológico. Assim, utilizo distinções básicas para referir-me a essas categorias, quais sejam: autor como o sujeito cujo nome aparece na capa do livro que produziu, narrador como a voz que narra a história de um certo ponto de vista e personagem como partícipe das ações narradas.

${ }^{3}$ Em um dos artigos consultados (PINHEIRO; ASSIS; MORAIS, 2008, p. 3), há referência à avó paterna de Alice como tendo o sobrenome Morley: a inglesa de descendência nobre se chamaria Alice Morley Dayrell, casada com John Lucy Smith Dayrell. Porém, a origem do uso de Morley no pseudônimo usado por Alice Brant permanece aqui incerta no que tange a uma possível relação a familiares antepassados. Em consulta a um site da genealogia familiar dos Dayrell, escrito por Márcio Dayrell Batitucci, observase que ali constam documentos que trazem o nome Alice Rice Callender para a avó inglesa de Alice Brandt, sendo que por muito tempo o sobrenome Morley teria sido atribuído à matriarca por parentes que supuseram a homenagem da neta em livro - suposição que seria desfeita com a posterior comprovação 
diversos episódios vividos por ela e seus familiares e vizinhos entre os anos de 1893 e 1895, na cidade mineira de Diamantina. O subtítulo à primeira edição de Minha vida de menina, "Cadernos de uma menina provinciana nos fins do século XIX", revela uma série de informações que inauguram a leitura. Os paratextos ali inclusos são variados: há a indicação do gênero textual adotado - os "cadernos" como anotações com forte presença do cotidiano; há a menção ao sujeito-da-enunciação responsável pelo plano enunciativo - a menina Helena -, que incide também na questão da identidade de gênero e idade na figura da jovem mulher que fala; e, ainda, há a referência aos dados contextuais que relacionam a característica provinciana ao período sócio-histórico correspondente - o final do século XIX.

Com o exemplo desses dados circundantes à obra, a autoria, portanto, ganha em importância na leitura. Há, nesses diários, a construção de um sujeito, elaborado segundo características da sua psicologia e da vida em uma dada sociedade. É verdade, porém, que mesmo que a autoria possa assumir uma posição central nesse livro, ela nem por isso é menos suscetível a níveis de desconstrução. A própria existência do pseudônimo adotado por Alice Brant pode ser o elemento inicial gerador da instabilidade na relação pessoa-autor e de questionamentos daí decorrentes.

Ademais, após o advento de correntes teóricas e hermenêuticas que passaram a se deter menos na figura do autor empírico, enquanto sujeito imediatamente definível e localizável - no âmbito de uma visão positivista da História -, e mais nas noções de efeito e recepção das inter-relações do público com as obras artísticas, passou-se a aceitar que, uma vez que a obra é publicada (ou seja, tornada pública), o autor, conforme preconizou Roland Barthes, morre em favor do espaço privilegiado ocupado agora pelo leitor ${ }^{4}$. Uma das consequências disso é que, considerando a obra em si, a categoria do narrador passe a ocasionar os maiores ofuscamentos no jogo espelhado da escrita autobiográfica. Isso porque esse narrador é o que se expõe de fato no nível textual desse tipo de escrita, colocando em jogo praticamente todas as cartas da mesa discursiva autodiegética. Em outros termos: esse narrador chama para si a responsabilidade pelo discurso, pois, ao assumir a voz em primeira pessoa, dá à obra e

documental consultada pela família Dayrell. Disponível em: <http://www.familiadayrell.uaivip.com.br./ johnalice.htm>. Acesso em: 27 abr. 2016.

${ }^{4}$ BARTHES, Roland. A morte do autor. In: O Rumor da Língua. São Paulo: Martins Fontes, 2004. 
aos seus conteúdos o forte caráter autorreferencial de uma subjetividade, centrada no sujeito-da-enunciação que é um "eu”.

O leitor, por seu turno, está no direito de desconfiar da voz desse narrador, questionando, por exemplo, a visão - e a versão - unilateral dos fatos adotada pelo narrador-protagonista. De acordo com a tipologia de narradores elaborada por Norman Friedman $(1967)^{5}$, o narrador-protagonista narra de um centro fixo, limitado quase que exclusivamente às suas percepções, pensamentos e sentimentos (FRIEDMAN, 2002, p. 177), aspectos os quais podem ser analisados pelos leitores em termos da presença ou da afirmação de uma possível parcialidade da voz que narra.

Em Minha vida de menina, a narração, como se disse, se dá pela voz de uma adolescente, no período dos seus doze aos quinze anos. A escrita é tanto subjetiva, no sentido de fazer reflexões sobre si, quanto objetiva, relatando situações que envolvem as ações de uma ou mais personagens. Por vezes, esses dois planos se juntam, como pode ser percebido no trecho a seguir, na entrada de "Quinta-feira, 16 de março [de 1893]", trazida na íntegra:

Eu acho que se fosse má seria mais feliz do que sou. Pelo menos não teria tanta pena de tudo como tenho, nem sofreria como sofro de ver os outros fazerem tanta maldade.

$\mathrm{Eu}$ gostava muito das Correias, duas amigas de mamãe aqui da vizinhança, porque pensava que elas eram boas. Mas hoje mamãe me mandou levar umas broas para as duas e eu entrei na hora em que elas estavam fazendo uma maldade horrível. Arrependi-me de ter ido levar o presente e tomei raiva delas. Elas estavam enforcando um gato na maior satisfação. Uma segurava a corda numa ponta, outra noutra, e o gato dependurado. Larguei o prato em cima da mesa e corri para a casa.

Elas vieram explicar a mamãe que foi porque o gato tinha furtado a carne. Mamãe lhes disse: "Helena é assim mesmo, tem pena de tudo". (MORLEY, 1998, p. 38).

Aqui, a subjetividade e a objetividade são aspectos simultâneos, de sorte que não conseguimos distinguir se o que dera origem ao registro foi o pequeno trauma causado pelo evento presenciado - a violência contra o bichano -, ou se foi a constatação prévia de que a narradora se veja como uma pessoa boa em meio a outras más - a partir da oração subordinada condicional que abre o trecho, pressupondo, mediante a condição

\footnotetext{
${ }^{5}$ FRIEDMAN, Norman. O ponto de vista na ficção: o desenvolvimento de um conceito crítico. Revista $U S P, n^{\circ}$ 53. Trad. Fábio Fonseca de Melo. São Paulo: Edusp, 2002. p. 167-182.
} 
criada, a hipótese de que ela poderia vir a se tornar diferente do que acredita ser -, sendo o evento, então, um pretexto para a autoavaliação positiva.

Vale acrescentar que essa dupla articulação gerada pelos registros - ora aparentes frutos de autoanálise, ora relatos de situações e/ou anedotas da vida cotidiana - é percebida durante todo o livro, em que impressionam a verve especial da narradoraprotagonista e a envolvência da narrativa, aspectos os quais causam não menos estranhamento e desconfiança no leitor.

Helena, citada por meio da fala transcrita da mãe no trecho do livro apresentado acima, é nominalmente a protagonista da narrativa, concordando com o nome escrito na capa do livro. Assim, a categoria personagem é também, por fim, partícipe da elaboração discursiva do "eu" em Minha vida de menina, constituindo, ao lado das categorias de narrador e autor, a tríade que, sendo coincidente, institui o pacto autobiográfico para a leitura. Esse pacto, porém e novamente, é pouco preciso e definitivo.

Um exemplo da problemática que surge no que tange à categoria do autor e, em menor ou maior grau, do narrador, é a incerteza acerca da elaboração original dos registros e a publicação da obra nos anos de 1940, aos sessenta e dois anos de Alice Brant. Tal problemática é de certa forma esperada, uma vez que o livro se trata da publicação de um diário de uma menina/adolescente, cujo interesse maior se explica tanto por certo ineditismo da obra no cenário literário da época ${ }^{6}$ quanto pelas suas qualidades narrativas e formais, colocando-se no meio do caminho do documento e da ficção.

A fortuna crítica consultada levanta pelo menos três hipóteses sobre a origem e a publicação dos diários. Essas hipóteses são mencionadas no ensaio que Roberto Schwarz dedica à obra, intitulado "Outra Capitu”, publicado em Duas meninas (1997). A primeira hipótese vem da própria Alice Brant, sustentando que o livro foi realmente

\footnotetext{
${ }^{6}$ Inicialmente, pode-se pontuar duas perspectivas nas quais Minha vida de menina adquira importância na tradição do diário enquanto gênero literário. De um lado, a publicação do diário de Helena Morley, considerado a partir do viés ficcional, talvez tenha como antecessor literário imediato, no Brasil, o último livro de Machado de Assis publicado ainda em vida do autor, Memorial de Aires, de 1908. Nessa obra, Machado explora com propriedade as características estruturais do diário ficcional, construindo, por entre as entradas datadas - algumas delas com mais de um registro por dia -, um narrador em primeira pessoa que interpola explicações, introduz falas das personagens e atualiza o leitor com informações diversas. De outro lado, o caráter confessional do diário de Morley, se tomado na perspectiva da autoria feminina juvenil, pode ser relacionado à obra máxima do gênero: O diário de Anne Frank. Cumpre salientar, porém, que o sucesso de Minha vida de menina não veio na esteira desse fenômeno internacional, mesmo porque foi publicado antes dele (o livro de Anne Frank é de 1947, e o de Morley, de 1942).
} 
escrito por ela nas mesmas datas que são apresentadas no diário, de 1893 a 1895 , quando ela tinha entre doze e quinze anos. A segunda hipótese, levantada certa vez por Alexandre Eulálio (1932-1988), era a de que a autora teria escrito seu livro já adulta, baseando-se nas memórias de juventude e simulando uma linguagem adolescente. Tempos depois, Eulálio reviu essa argumentação e concluiu que os escritos são da jovem Alice, mas que teriam sido editados, ao menos em parte, na versão publicada. A terceira e última hipótese, que é a adotada por Schwarz, é a de que a autora teria melhorado seu texto de menina para a publicação, já revelando, na opinião do crítico, certos ideais modernistas, como a liberdade linguística e a difusão da língua "brasileira" (SCHWARZ, 1997, p. 45-46 apud RECCHIA \& LEONEL, 2011, p. 6-7).

Especulações acerca da suposta participação autoritária do marido de Alice, Augusto Mário Caldeira Brant (1876-1968), também são frequentes. Ele teria inclusive insistido para que a esposa publicasse o diário. Além disso, diz-se que foi ele o coletor e organizador de boa parte dos registros, bem como teria sido uma espécie de censor: em entrevista ao jornal $O$ Globo, Alice revela que o marido havia "suprimido muita coisa que parecesse indiscreta, por atingir, através de críticas, pessoas ainda vivas" (MACHADO, 2000, p. 60 apud RECCHIA \& LEONEL, 2011, p. 8) ${ }^{7}$.

Ainda que instigantes, considero que os enigmáticos contextos de produção e publicação de Minha vida de menina correspondam a apenas uma parcela do interesse múltiplo que essa obra pode gerar. No caso de Brant/Morley, se, por um lado, a categoria do autor, ao ser analisada juntamente aos aspectos biográficos da pessoa que assina o livro, pode desestabilizar a força autoral, por outro lado, a ciência desses aspectos, sejam eles conferidos pelos paratextos do livro ou por uma pesquisa mais detalhada das possibilidades editoriais, faz com que o texto passe a provocar ainda mais o leitor, que se vê diante de uma sequência de eventos relativamente pueris contados por uma voz fluente e autêntica. É claro que - assim como fizeram Alexandre Eulálio e Roberto Scharwz - podemos desconfiar dessa voz, sem saber até que ponto os registros seriam amostragens reais da escrita juvenil. Sendo assim, vale ressaltar que, caso houvesse comprovação de que o diário de Helena Morley se trata de uma produção

\footnotetext{
7 Essa entrevista, cuja data não fora encontrada, é citada na tese de doutoramento de Maria Teresa Almeida Machado, intitulada Para inglês ler: o diário de Helena Morley traduzido por Elizabeth Bishop, defendida no ano de 2000 junto à Faculdade de Filosofia, Letras e Ciências Humanas da Universidade de São Paulo. A tese não se encontra disponível para consulta online.
} 
muito posterior ao período dos registros atribuído pela autora, poderíamos concordar com João Guimarães Rosa quando ele afirma que estaríamos diante de um caso ainda mais extraordinário na literatura brasileira, pois Rosa não encontrara antes desse diário nenhuma outra obra que representasse de maneira tão literal a infância ${ }^{8}$.

Com tais questões em aberto, prossigamos, então, a algumas reflexões que podem emergir do variado campo discursivo composto pelas 275 entradas do diário da menina provinciana - obra que, conforme Alexandre Eulálio, nascera clássica.

\title{
2. Segunda parte: algumas discussões
}

Inicio essa parte com a citação a um trecho da "Nota à $1^{a}$ edição" do livro, assinada em 1942 por "Helena Morley" (como dissemos, pseudônimo de Alice Brant):

\begin{abstract}
Não sei se poderá interessar ao leitor de hoje a vida corrente de uma cidade do interior, no fim do século passado, através das impressões de uma menina, de uma cidade sem luz elétrica, água canalizada, telefone, nem mesmo padaria, quando se vivia contente com pouco, sem as preocupações de hoje. E como a vida era boa naquele tempo! Quanto desabafo, quantas queixas, quantos casos sobre os tios, as primas, os professores, as colegas e as amigas, coisas de que não poderia mais me lembrar, depois de tantos anos, encontrei agora nos meus cadernos antigos! (MORLEY, 1998, p. 13).
\end{abstract}

O entusiasmo de Morley ao falar sobre tempos pretéritos, os quais teriam sido reconstruídos pelos diários mantidos por ela naquele tempo, faz com que o leitor, invocado indireta, mas explicitamente, sinta-se instigado e curioso pelo que está por vir. Essa passagem, retirada de nota introdutória dessa obra, adquire, portanto, um quê de ironia - que lembra, enfim, a tão mencionada ironia machadiana, aquela da ordem da interação provocativa do narrador para com o leitor. Assim, as qualidades narrativas, inegáveis na construção dos diários de Morley, talvez não expliquem tanto a natureza desse tom irônico quanto a surpreendente repercussão crítica da obra. Minha vida de menina interessa - e muito - até hoje, sendo ainda incipiente, mas diversificada, a fortuna crítica a seu respeito. Isso sem nos esquecermos das impressões positivas sobre a obra causadas em leitores como Raquel de Queiroz, o já citado João Guimarães Rosa,

\footnotetext{
${ }^{8}$ A observação de Guimarães Rosa é citada por Alexandre Eulálio em "Livro que nasceu clássico", texto de introdução à edição de 1979 de Minha vida de menina pela editora Companhia das Letras, com a $5^{\text {a }}$ reimpressão datada de 1998. p. 8.
} 
Gilberto Freyre, Carlos Drummond de Andrade, Mário de Andrade, Rubem Braga e Elisabeth Bishop (cuja tradução da obra para o inglês, intitulada The Diary of "Helena Morley”, fora lançada em 1957), cabendo citar, também, a adaptação fílmica Vida de menina, dirigida por Helena Solberg e lançada em 2004.

Minha vida de menina, ao ser escrito na forma tradicional de um diário, convida o leitor a ingressar em um universo de recordações e impressões pessoais da narradora Helena. Nas entradas, datadas, chamam a atenção tanto os eventos históricos, mencionados em alguns registros em tom de comentário cotidiano, quanto os acontecimentos e as reflexões sobre o dia a dia de uma adolescente em uma cidade pacata das Minas Gerais oitocentista. A voz de Helena, contudo, ainda que descompromissada e leve, é bastante questionadora, e esconde um gênio quase que marginalizado, muitas vezes deslocado no universo das convenções do comportamento social, da religião e da educação da sua época.

O papel em branco serve a Helena como um repositório de fatos da memória individual e coletiva, fatos que ora revelam um encanto em relação à vida, ora expõem os desconfortos da jovem mulher no seio social ${ }^{9}$. A menina, contudo, parece não entender muito bem como se dá o seu processo de escrita. Na entrada de "Quarta-feira, 20 de dezembro [de 1893]", a narradora comenta sobre a facilidade que tem para escrever - fato que espanta a sua avó materna, Dona Teodora, mas, para Helena, adquire uma naturalidade acriançada. Diz a narradora:

Mamãe nunca olha o que eu escrevo, mas vovó quer que eu leia tudo pra ela e também para as pessoas de fora. [...] Coitada; ela [avó] é muito inteligente, mas mal aprendeu a ler e escrever e por isso fica pensando que é uma coisa do outro mundo contar as coisas com a pena. Engraçado é que ela não se admira de eu contar com a boca. É que ela pensa que escrever é mais custoso. (MORLEY, 1998, p. 114).

Em outro momento do texto, na entrada de "Domingo, 19 de maio [de 1895]", Helena diz que, sempre ao pegar a pena, as memórias da infância simplesmente lhe surgem, como nos momentos em que rememora os seus primeiros anos de vida, quando brincava com bonecas de pano ou carregava, por divertimento, os filhos dos vizinhos. A narradora tenta esboçar uma explicação para essa facilidade incitada pela página,

\footnotetext{
${ }^{9} \mathrm{O}$ principal texto consultado sobre a questão memorialística em Minha vida de menina é de Neukirchen (2005), embora tal texto tenha influído pouco na escrita desse artigo.
} 
calcada na memória: "talvez porque naquela época coisas pequenas me impressionassem mais, e eu guardo tudo muito." (MORLEY, 1998, p. 253).

Há, no mínimo, outras duas vantagens que o hábito da escrita adquire nos diários de Morley. Uma delas é a função de uma espécie de confessionário; outra, como um tipo de autopreservação. A primeira é da ordem da confiança que a menina atribui ao seu caderno, na qualidade de "confidente e amigo único" (MORLEY, 1998, p. 205). A segunda é a atribuição que, a rigor, o pai da menina, o grande incentivador para a composição dos diários, confere à escrita. Como exemplo, temos o registro de "Segunda-feira, 24 de julho [de 1893]", o qual traz a possibilidade da preservação tanto da memória quanto da integridade individual, por meio do emprego das letras:

Cada dia acho mais razão no conselho de meu pai de escrever no meu caderno o que penso ou vejo acontecer. Ele me disse: "Escreva o que se passar com você, sem precisar contar às suas amigas e guarde neste caderno para o futuro as suas recordações". (MORLEY, 1998, p. 68).

Outro aspecto que surge da leitura de Minha vida de menina é a autorrepresentação vívida da infância ${ }^{10}$. Helena, que se encontra em um estado intermediário entre a infância e a idade adulta (considerando-se que, naquela época, a adolescência ainda não era estudada como um estágio de desenvolvimento vital distinto), goza de um tipo de liberdade que lhe é garantida em virtude de estar vivendo essa fase relativamente invulnerável (FISCHER, 1998, p. 178). Acrescenta-se a isso a personalidade questionadora e curiosa da menina, que não se rende à passividade ou à hesitação; ao contrário, ela em geral faz das suas aflições material para uma reflexão aguçada sobre si mesma, denotando uma sabedoria precoce que, a partir da interpretação do leitor, abre espaço para a percepção da ironia e da ambiguidade.

Graças à sua inteligência, energia e desenvoltura, Helena é querida por muitos. No entanto, sua postura distinta e viva a coloca numa posição de destaque, a ponto de, às vezes, quase sufocá-la, ao retirá-la do lugar lúdico ocupado pela criança, lugar que, via de regra, mantém um distanciamento em relação à seriedade do mundo adulto. Como resultado desse seu comportamento, destoante ao das outras crianças, Helena sente-se confusa e sofre com o excesso de atenção que recebe, como pode ser aferido pelo trecho a seguir:

10 Sobre a infância representada na obra de Morley, apoiei-me em Fischer (1998) e Fritzen \& Cabral (2008). 
Sábado, 13 de outubro [de 1894]

Poderá alguém compreender como é que uma pessoa que gosta muito de outra tenha jeito de aborrecê-la?

O caso de tia Madge comigo é o mais esquisito que eu já vi. Ela é minha madrinha de crisma e eu sei que ela é quase como vovó para me achar qualidades. Eu não posso lhe contar um caso que ela ri até mais não poder. Diz a todos que eu sou inteligente, espirituosa e boa. Tudo que uma pessoa possa fazer por outra, tia Madge faz por mim. E eu posso dizer que quase todos os aborrecimentos que tenho tido na vida são causados por ela com essa mania de se interessar tanto por mim. Eu seria muito mais feliz se ela fosse como as outras tias, que nem olham o que eu faço. Mas ela, coitada, tudo que faz de bom é para me dar um aborrecimento e às vezes sofrimento. (MORLEY, 1998, p. 194).

Uma segunda consideração quanto à vida na infância representada na obra é a que surge a partir da perspectiva da autora, já adulta e avó, como expresso na nota à primeira edição, de 1942. A infância de Brant/Morley, nesse olhar retrospectivo, teria acontecido em um momento de "existência simples" (MORLEY, 1998, p. 13), sendo representada aqui como uma época de "hedonismo inocente" (FRITZEN \& CABRAL, 2008, p. 51), em nome da pureza e da leveza de espírito. O livro, então, é praticamente dedicado - e até direcionado - a uma outra geração da infância, em caráter de ensinamento moral. Nas palavras de Morley nessa nota:

Agora uma palavra às minhas netas. - Vocês que já nasceram na abastança e ficaram tão comovidas quando leram alguns episódios de minha infância, não precisam ter pena das meninas pobres, pelo fato de serem pobres. Nós éramos tão felizes! A felicidade não consiste em bens materiais mas na harmonia do lar, na afeição entre a família, na vida simples, sem ambições - coisas que a fortuna não traz, e muitas vezes leva. (MORLEY, 1998, p. 14).

Ainda contemplando a representação da infância, mas numa perspectiva de gênero e idade, Britta Fischer (1998) pontua que existem inúmeras evidências, nos relatos de Helena, de que ela esteja vivendo em uma espécie de limbo existencial: sendo não mais criança e ainda não adulta. No tocante a aspectos cognitivos, Fischer diz que, na idade aproximada dos 9 aos 14 anos, "as meninas são por um lado capazes e empreendedoras e, por outro, ainda não são constrangidas pelas exigências impostas às jovens no sentido de serem comportadas e respeitáveis" (FISCHER, 1998, p. 178). Assim, é precisamente nessa fase que a molequice e a curiosidade das meninas 
corresponderiam a um comportamento normal. Além disso, essa é a "única época em que as garotas são aceitas pelos meninos como quase-iguais e podem vivenciar aventuras que eles consideram um direito de nascença” (FISCHER, 1998, p. 178).

Seria possível acompanhar, então, um processo de desenvolvimento psíquico da protagonista que narra Minha vida de menina, levando em conta o período da préadolescência vivido pela jovem menina no transcorrer dos quase três anos em que os eventos narrados acontecem. Naturalmente, esse processo não se dá apenas no nível biológico ou psicológico, mas também de acordo com uma construção social que depende amplamente de classe, raça, período histórico e normas culturais. Relacionado a esses aspectos, observa-se, também, o conflito de gerações, representado em vários momentos da obra. Helena, então, é a mistura de uma moça, branca, de classe média, crescida num contexto caseiro mais liberal, com uma menina atrevida de personalidade livre. A mãe de Helena, chamada Carolina nos relatos, é a primeira a sofrer com os atrevimentos da menina. Na entrada de "Segunda-feira, 18 de março [de 1895]", notamos algumas divergências entre as percepções de mundo de mãe e filha.

Poucas são as vezes que entro em casa que mamãe não repita o verso:

A mulher e a galinha

Nunca devem passear,

A galinha bicho come,

A mulher dá que falar.

E depois diz: "Era por minha mãe nos repetir sempre este conselho, que fomos umas moças tão recatadas. Vinham rapazes de longe nos pedir em casamento pela nossa fama de moças caseiras".

Eu sempre respondo: "As senhoras eram caseiras porque moravam na Lomba. E depois, a fama foi o caldeirão de diamantes que vovô encontrou. Moça caseira, a senhora não vê que não pode ter fama? Como? Se ninguém a vê?". (MORLEY, 1998, p. 236).

Um outro ponto de análise parte do ensaio, já citado, que Roberto Schwarz dedicou à obra de Morley ${ }^{11}$. Schwarz analisa a figura e a voz admiráveis de Helena a partir da formação de traços característicos, especialmente em termos de transformações macrossociais associadas a raça e classe. Desse modo, o crítico faz uma leitura da posição histórica que a menina assume naquela época. Para ele, "a transição social e histórica na estrutura econômica e de classes do Brasil fornece o solo fértil a partir do

11 Também parto de Britta Fischer (1998) para discutir as colocações de Schwarz (1997), uma vez que a autora, no seu texto, traz a todo o momento as considerações do crítico acerca de Minha vida de menina. 
qual as ideias humanísticas, não-convencionais e multilaterais de Helena Morley podem se constituir." (FISCHER, 1998, p. 175-176).

São destacados, aqui, pontos como a brutalidade da escravidão e a desumanização do trabalho assalariado. A principal conclusão de Schwarz é a de que

a percepção de Helena Morley é facilitada por dois principais fatores externos. Primeiro, há a realidade histórica daquele curto período em que a escravidão acabava de ser abolida e o trabalho assalariado ainda não havia se estabelecido de modo sistemático. Este período constitui um "interregno" no qual as normas dominantes, que governaram as relações sociais durante séculos, foram parcialmente suspensas, deixando os habitantes da região numa espécie de anomia ou terra-deninguém normativa. Segundo, a área de mineração de diamantes em Minas Gerais estava em declínio econômico em razão do esgotamento das pedras preciosas. Para alguns, esta situação exigiu um recuo à economia de subsistência. (FISCHER, 1998, p. 176, destaque da autora).

Tais mudanças na estrutura social da época ocasionaram a improvisação de outras formas de relações econômicas e sociais. Nesse contexto, os antigos escravos experimentaram no mínimo três diferentes situações: uns beneficiaram-se por meio da educação; outros, mudaram-se; outros, continuaram dependentes das famílias mais abastadas que outrora os tinham como cativos. Essa terceira situação relaciona-se ao cenário vivido pela avó de Helena. Na entrada de "Domingo, 9 de dezembro [de 1894]", a permanência dos escravos depois da Lei Áurea é comentada por Helena a partir do ponto de vista da senhoria, inserido na forma do discurso indireto:

Eu ainda me lembro de quando chegou a notícia da Lei de Treze de Maio. Os negros todos largaram o serviço e se ajuntaram no terreiro, dançando e cantando que estavam livres e não queriam mais trabalhar. Vovó, com raiva da gritaria, chegou à porta ameaçando com a bengala dizendo: "Pisem já de minha casa pra fora, seus tratantes! A liberdade veio não foi pra vocês não, foi pra mim! Saiam já!”. Os negros calaram o bico e foram para a senzala. Daí a pouco veio Joaquim Angola em nome dos outros pedir perdão e dizer que todos queriam ficar. (MORLEY, 1998, p. 211).

Nessa mesma época, ocorreu a derrocada da economia do diamante, que afetara sobremaneira a família de Helena. O pai, de nome Alexandre nos relatos, era um dos poucos mineradores remanescentes, que mal conseguia suprir financeiramente a própria casa. Pela voz da filha, o pai é apresentado como alguém que não soube lidar com a 
crise do extrativismo e insistia na atividade mesmo com o insucesso nos resultados. $\mathrm{O}$ trecho a seguir, da entrada de "Sábado, 5 de agosto [de 1893]", evidencia o declínio da extração de diamantes e no que isso afetava a família da menina:

$\mathrm{Eu}$, tirando meu título de normalista, sei que tudo vai melhorar, pois irei até para o fim do mundo dar minha escola. Já fiz meus planos, tão bem assentadinhos, que até poderemos guardar dinheiro. Mas deixar meu pai nesta peleja, furando a terra à espera de diamantes que não aparecem, é que não deixarei. Às vezes eu dou razão a Seu Zé da Mata, da resposta que ele deu quando meu pai o foi convidar para entrar de sociedade num serviço de mineração. Ele disse: "Não, Seu Alexandre, eu não deixo o meu negócio onde estou vendo o que tenho, para procurar debaixo da terra o que eu não guardei lá!” (MORLEY, 1998, p. 71).

Como consequência direta do esgotamento gradual da atividade mineradora, passou a ocorrer a suspenção da separação estrita entre trabalho manual e abstrato por classes sociais. Tal circunstância fez com que os brancos em decadência, como os Morley, passassem a realizar toda sorte de trabalho manual, a despeito de sua educação e privilégio (FISCHER, 1998, p. 176-7). Algumas das observações de Helena refletem bem esse cenário emergente de novas divisões sociais do trabalho. Em parte da entrada de "Quinta-feira, 26 de abril [de 1894]", lemos o seguinte:

Eu, de pequena, tinha inveja muitas vezes, mas hoje não tenho.

Agradeço muito isto a vovó. Foi ela que me corrigiu.

Eu sou a mais pobre da minha roda. Vejo a diferença da minha vida e das outras e não as invejo. Se elas soubessem os meus serviços em casa e na Chácara teriam pena de mim; no entanto eu gosto muito de todos eles. Em casa tenho de passar as roupas a ferro, fazer a arrumação e nas quintas-feiras arear a metade da casa. A outra metade é de Luisinha. Tenho de lavar meu uniforme e passá-lo. Também arrumação da cozinha nas quintas-feiras é minha. Eu mesma é que peço a mamãe para me deixar esse trabalho.

Na Chácara ajudo a apanhar jabuticabas e espremer para fazer vinagre, a apanhar café, a colher frutas. Ajudo a fazer molhos de verduras para vender, a fazer velas e outras coisas mais. Gosto de todos estes serviços, mas o melhor de todos é fazer velas, que é no terreiro com vovó assistindo. A gente vai metendo os pavios no sebo e pondo no varal. Quando secam, faz-se a mesma coisa outra vez até a vela ficar da grossura que se quer. Eu sou a mais ligeira e vovó fica satisfeita de ver como eu ando depressa. Vovó é a única pessoa que não quer me ver trabalhar muito; ela só gosta que eu estude. 
Não sei por que até hoje todo o mundo diz que tinha pena dos escravos. Eu não penso assim. Acho que se fosse obrigada a trabalhar o dia inteiro não seria infeliz. Ser obrigada a ficar à toa é que seria castigo para mim. Mamãe às vezes diz que ela até deseja que eu fique preguiçosa; a minha esperteza é que a amofina. Eu então respondo: "Se eu fosse preguiçosa não sei o que seria da senhora, meu pai e meus irmãos, sem uma empregada em casa". Palavra que eu tinha vontade de deixar as coisas correrem aqui em casa sem eu fazer, só para ver. Mas não posso. (MORLEY, 1998, p. 148-9).

Nessa passagem, Helena traz uma relação extensa de tarefas domésticas (e até de produção caseira para venda) executadas rotineiramente por ela e também pela avó e pela irmã mais nova, Luisinha, além das atividades que precisam ser exercidas pela mãe na falta de empregadas domésticas que realizem as tarefas da casa, dadas as dificuldades financeiras da família. De nossa parte, é interessante notar como a menina presta um elogio ao trabalho e diz que prefere a ocupação intensa a alguma parcela de ócio que, segundo ela, levaria à preguiça. Nesse mesmo aspecto, podemos perceber, porém, certa ingenuidade de Helena ao comentar, nesse registro, sobre o trabalho escravo como algo positivo pelo simples fato de - na cabeça da menina - manter a pessoa ativa e produtiva. Entendo, contudo, que antes de defender o sistema escravocrata, a jovem esteja na verdade reproduzindo o novo contexto de trabalho no qual a sua própria família e certamente outras estavam vivendo na época, além de reforçar a imagem de uma menina esperta e desenvolta, que assume certas responsabilidades com bastante seriedade.

\section{Considerações finais}

Ainda que atualmente pouco lido e, talvez, até esquecido, os leitores do único livro de Alice Brant/Helena Morley são quase sempre contagiados pela força da impressão de Alexandre Eulálio, que toma Minha vida de menina como um "livro que nascera clássico". Alguns dos motivos (motifs) explorados pelo livro que em alguma medida justificam a impressão de Eulálio e de muitos outros leitores foram, aqui, brevemente comentados. Mas, assim como toda obra clássica, Minha vida de menina não se esgota em leituras rápidas; ficam sempre abertos os convites a investigações mais aprofundadas sobre cada um dos seus eixos temáticos possíveis. 
Nessa obra singular, temos, em síntese, o diário de uma jovem e espirituosa adolescente, que se passa no cenário complexo de um Brasil rural e patriarcal do final do século XIX e é repleto de observações sobre fatos, hábitos, crendices e relações sociais que circundam a narradora-protagonista Helena. Pelas páginas de Minha vida de menina, podemos transitar sem impedimento dos estudos sobre a produção de autoria feminina para os fatos do nascimento do estado republicano brasileiro, das considerações sobre a escrita do diário autobiográfico para as questões da autoria e da configuração do "eu" que narra, do cotidiano de uma menina de família abastada para as novas divisões do trabalho ocasionadas pelas transformações econômicas da transição para o século XX, dentre outras pontes possíveis que liguem temas distintos.

Ao livro Minha vida de menina cabe bem a alcunha de "clássico" porque, em obras como essa, o leitor atrela-se a um gênio, a uma singularidade subjetiva que, mais do que se relacionar à figura empírica de um autor, prende-se a um certo discurso. Esse discurso, ao qual nós leitores temos pleno acesso, é ao mesmo tempo aberto enquanto obra artística e colado a uma época regida por determinadas mentalidades e convenções.

É assim que Minha vida de menina, de valor inestimável e de surpresas inesgotáveis, torna-se um dos maiores diamantes já saídos de Diamantina.

\section{REFERÊNCIAS}

BARTHES, Roland. A morte do autor. In: O Rumor da Língua. São Paulo: Martins Fontes, 2004.

FISCHER, Britta. As experiências de liberdade de Helena Morley. Trad. Heloísa Buarque de Almeida. Novos Estudos - CEBRAP, n. 51, jul. 1998. p. 175-188. Disponível em:

http://novosestudos.uol.com.br/v1/files/uploads/contents/85/20080627_as_experiencias. pdf. Acesso em: 28 nov. 2015.

FRIEDMAN, Norman. O ponto de vista na ficção: o desenvolvimento de um conceito crítico. Revista USP, n. 53. Trad. Fábio Fonseca de Melo. São Paulo: Edusp, 2002. p. 167-182.

FRITZEN, Celdon \& CABRAL, Gladir da S. Minha vida de menina, Infância e Os bichos que tive: o gênero autobiográfico e a representação da infância na literatura. Resgate. Revista Interdisciplinar de Cultura, n. 17, 2008. p. 45-60. Disponível em: 
http://www.cmu.unicamp.br/seer/index.php/resgate/article/view/228/232. Acesso em: 27 nov. 2015.

LEJEUNE, Philippe. O pacto autobiográfico: de Rousseau à Internet. Trad. Jovita Maria Gerheim Noronha e Maria Inês Coimbra Guedes. Belo Horizonte: Ed. UFMG, 2008. (Coleção Humanitas).

MEYER, Marlise. Uma tradução e suas circunstâncias. Literatura e Sociedade, n. 9, 2006. p. 278-290. Disponível em:

http://www.revistas.usp.br/ls/article/view/23591/25628. Acesso em: 28 nov. 2015.

MORLEY, Helena. Minha vida de menina. $5^{\text {a }}$ reimp. São Paulo: Companhia das Letras, 1998.

NEUKIRCHEN, Clarice B. S. A arte de rememorar na obra Minha vida de menina. Revista Trama. v. 1, n. 2, 2005. Disponível em:

http://e-evista.unioeste.br/index.php/trama/article/view/209/144. Acesso em: 27 nov. 2015.

PINHEIRO, Mariza de O; ASSIS, Geisa M. S. de; MORAIS, Maria A. C. de. Minha vida de menina, o diário clássico de Diamantina como prática cultural da escrita de si. Anais. V Congresso Brasileiro de História da Educação. 2008. Disponível em: http://www.sbhe.org.br/novo/congressos/cbhe5/pdf/776.pdf. Acesso em: 27 nov. 2015.

RECCHIA, Cristal R. \& LEONEL, Maria Célia de M. Diamantina: cenário do primeiro diário escrito por uma mulher no Brasil - Minha vida de menina de Helena Morley. Recorte - revista eletrônica. v. 8, n. 2, 2011. Disponível em:

http://revistas.unincor.br/index.php/recorte/issue/view/45. Acesso em: 27 nov. 2015. 